\title{
Plavecká úroveň studentů Univerzity Tomáše Bati ve Zlíně v letech 2002-2013
}

\section{Swimming competence of Thomas Bata University Zlín students in 2002-2013}

\author{
Miroslava Dolejšová, Zdeněk Melichárek, Marcela Kubalčiková \\ Fakulta managementu a ekonomiky Univerzity Tomáše Bati ve Zlíně
}

\begin{abstract}
Abstrakt
Cílem článku je porovnání plavecké zdatnosti studentů naší univerzity. Zajímalo nás, zda si neplavci mohou zlepšit plaveckou zdatnost na konci plaveckého výcviku, zda se studenti na konci plaveckého výcviku zlepšili a zda se změnila plavecká zdatnost studentů za 10 let.

První ćást analýzy se vztahovala k letům 2007 až 2013. Zjištovali jsme, zda jsou neplavci schopni zlepšit si svou plaveckou zdatnost a zda se studenti na konci plaveckého výcviku zlepšili. K analýze dat jsme použili proporční testy. Druhá část analýzy se týkala let 2002 a 2012. K dispozici jsme měli naměřené časy studentů na počátku a na konci plaveckého výcviku. Zajímalo nás, zda se změnila plavecká zdatnost studentů za 10 let. K porovnání zlepšení studentů v letech 2002 a 2012 jsme použili párový Wilcoxonův test. K porovnání plavecké zdatnosti studentů za 10 let jsme použili nepárový (dvouvýběrový) Wilcoxonův test.

Zjistili jsme, že z celkového počtu 145 neplavců se 138 na konci plaveckého výcviku zlepšilo. Bylo prokázáno, že neplavci tvoři méně než $10 \%$ z celkového počtu studentů. V akademických letech 2007/2008, 2011/2012 a 2012/2013 se zlepšili všichni neplavci. 92 neplavců uplavalo časový limit 100 metrů. Prokázali jsme, že se $60 \%$ neplavců na konci plaveckého výcviku zlepšilo.

Dále jsme zjistili, že třetina studentů neuplavala limit 100 metrů. Požadovaný limit uplavalo 1029 studentů. Na konci plaveckého výcviku se zlepšilo 3432 studentů. Plavecká zdatnost studentů se v letech 2002 i 2012 zlepšila. Plavecká zdatnost studentů se zlepšila i za 10 let.

Téměř všechny statistické hypotézy se nám podařilo na hladině významnosti 0,05 prokázat a můžeme je považovat za statisticky významné.

Postup, který jsme použili k analýze plavecké zdatnosti studentů Univerzity Tomáše Bati ve Zlíně, může být prínosný $k$ analýze plavecké zdatnosti nejen na dalších vysokých školách, ale i na různých pracovištích, která se zabývají měřením zdatnosti sportovců.
\end{abstract}

\footnotetext{
Abstract

The aim of this paper is to compare the swimming fitness of students at our university. We wanted to know whether the non-swimmers could improve their swimming fitness at the end of the swimming training. We wanted to know whether the students of our university improved their swimming fitness at the end of the swimming training. We wondered whether the swimming fitness of our university students has changed in 10 years.

The first part of the analysis covered the years 2007 to 2013. We examined whether the non-swimmers were able to improve the swimming fitness. At the same time we examined whether the students improved the swimming fitness at the end of the swimming training. We used the tests of proportions to analyse the data. The second part of the analysis covered the years 2002 and 2012. We measured the times of students both at the beginning and at the end of the swimming training in these years. We wondered whether the swimming fitness of university students has changed in 10 years. To compare the swimming fitness in 2002 and 2012 we used the Wilcoxon test for paired samples. To compare the swimming fitness in 10 years we applied the Mann-Whitney-Wilcoxon test.
} 
We found that 138 non-swimmers improved their swimming fitness at the end of the swimming training. It has been shown that non-swimmers made up less than $10 \%$ of the total number of students who attended the swimming training between the years 2007 and 2013. All non-swimmers improved in academic years 2007/2008, 2011/2012 and 2012/2013. 92 non-swimmers swam the limit of 100 meters. We have shown that $60 \%$ of non-swimmers improved their swimming fitness at the end of the swimming training.

Furthermore, we found that a third of students mismanaged to swim the limit of 100 meters. The required limit of 100 meters swam 1029 students. 3432 students improved the swimming fitness at the end of the swimming training.

Furthermore, we found that the swimming fitness of students improved both in 2002 and 2012. Finally, we found that the swimming fitness of our students has improved in 10 years.

We managed to prove almost all the statistical hypothesis at the significance level of 0.05 and therefore we could consider them to be statistically significant.

The procedure that we used to analyse the swimming fitness of students at the Tomas Bata University in Zlín may be beneficial for analysis of the swimming fitness not only at other universities, but in different workplaces that deal with measuring the performance of athletes.

Klíčová slova: Měření zdatnosti, plavecká zdatnost, Wilcoxonův test, proporční test.

Keywords: Fitness Measurement, Swimming Fitness, Wilcoxon Test, Test of Proportions.

\section{ÚVOD}

Pokládáme plavání v rámci sportovních aktivit na vysoké škole za důležitý článek plavecké výuky a za jednu, ne-li poslední možnost naučit se plavat. Vyučujeme plavání na univerzitě již 10 let a při své práci zjištujeme, že mezi vysokoškoláky, kteří by měli mít za sebou výuku plavání na základní i stř̌ední škole, je stále mnoho špatných plavců a dokonce neplavců. Většina těchto lidí by si plavání do svého rozvrhu dobrovolně nezařadila.

Podle Vodní záchranářské služby Českého červeného křiže (2013) utonulo v České republice od roku 2007 do roku 2012 celkem 1366 osob, z toho 1022 mužủ a 344 žen. Utonutí a potopení při pobytu v bazénu nejsou častá. $V$ roce 2012 utonuli 2 muži. U žen nejsou tyto př́ípady úmrtí typické. $\mathrm{V}$ roce 2007 utonulo při pobytu v bazénu 5 mužů. K utonutí a potopení po pádu do bazénu také nedochází často. $V$ roce 2012 nebyl zaznamenán takový př́ípad.

Daleko horší situace je při pobytu $v$ prrírodní vodě a při pádu do př́rodní vody. Obvykle muži jsou ti, kteří podceňují své síly. $V$ roce 2010 utonulo 26 mužů při pobytu v prrírodní vodě. $V$ roce 2009 utonulo 44 mužů při pádu do př́rodní vody.

Ženy jsou na tom o hodně lépe. V roce 2007 utonulo při pobytu v přírodní vodě 6 žen. $V$ roce 2010 utonulo 10 žen při pádu do prírodní vody.

Výzkumy v oblasti plavání je možné rozdělit do čtyř skupin: testy plaveckých dovedností souvisejících s výukou plavání, testy antropometrických charakteristik těla plavců, testování prostřednictvím trenažérů a testování plavecké zdatnosti.

K hodnocení plaveckých dovedností souvisejících s výukou plavání se nejčastěji použivají bodové škály. Stloukalová, Roztočil \& Vrabcová (2010) použili pětibodovou škálu pro skok střemhlav z okraje bazénu do vody, opakované výdechy do vody, splývavou polohu na prsou s odrazem od stěny, splývavou polohu na znak s odrazem od stěny a výlov dvou předmětů.

Na Univerzitě Tomáše Bati ve Zlíně porovnávala Martinková (2012) plaveckou úroveň mužů (studentů) a žen (studentek). Podobně jako Stloukalová, Roztočil \& Vrabcová (2010) použila pětibodovou škálu pro potopení hlavy, splývavou polohu na prsou a na zádech, výdech do vody, skok do vody z okraje bazénu, výlov dvou předmětů a přetočení kolem podélné osy. 
Merica \& Hlavatý (2010) použili k měření antropometrických charakteristik těla plavců deset antropometrických bodů. Labudová \& Matúš (2010) použili plavecký ergometr k testování silových schopností synchronizovaných plavkyň. Byla zjištována tělesná váha, výška postavy a index tělesné hmotnosti BMI.

Jánošíková (2010) analyzovala úspěšnost základního plaveckého výcviku u žákủ v Plavecké škole Valašské Meziříčí. Analyzováno bylo splývání v poloze na prsou, splývání v poloze na zádech a délka přeplavané vzdálenosti plaveckým způsobem prsa.

Mikyna (2013) analyzoval úroveň plaveckých dovedností studentů Fakulty sportovních studií Masarykovy univerzity v Brně. Testovány byly tři plavecké styly: kraul, prsa a znak.

V zahraničí jsou výzkumy plavecké zdatnosti zaměřeny na profesionální plavce. Arroyo-Toledo, Clemente \& Gonzáles-Ravé (2013) testovali plaveckou zdatnost u profesionálních plavkyn̆.

Většina článků i závěrečných prací je zaměřena do oblasti testování plaveckých dovedností. Tyto testy se soustředí na zvládnutí či nezvládnutí určité plavecké dovednosti. U plaveckých dovedností se obvykle neměří čas zvládnutí testované dovednosti. Měření antropometrických charakteristik těla plavců i testování silových schopností jsou sice pro plavání důležité, přesto příliš nesouvisejí s úrovní plavecké zdatnosti plavců.

Náš př́ispěvek je orientován do oblasti plavecké zdatnosti. V této výzkumné oblasti byly publikovány převážně bakalářské práce (Mikyna, 2013; Jánošíková, 2010).

\section{Výzkumný záměr}

Příspěvek se zaměřuje na plaveckou zdatnost studentů, konkrétně studentů Univerzity Tomáše Bati ve Zlíně. Cílem príspěvku je porovnání plavecké zdatnosti studentů v akademických letech 2007/2008 až 2012/2013. Zajímalo nás, zda se plavecká zdatnost našich studentů zlepšila, zhoršila či zůstala stejná. Kromě porovnání plavecké zdatnosti studentů nás zajímalo, jak se zdatnost studentů změnila za 10 let. Srovnávali jsme naměřené časy na začátku a konci plaveckého výcviku v akademických letech 2002/2003 a 2012/2013.

$\mathrm{K}$ analýze dat jsme použili jednoduché statistické testy. Poskytujeme dalším vysokým školám a dalším pracovištím, která se zabývají testováním zdatnosti sportovců, praktický návod, jak mohou analyzovat data podobným způsobem jako jsme to udělali my.

\section{Výzkumné otázky a statistické hypotézy}

Pro účely analýzy jsme si stanovili následující výzkumné otázky a k nim př́islušné statistické hypotézy.

První výzkumná otázka: Jsou neplavci schopni zlepšit si svou plaveckou zdatnost po absolvování výuky plavání?

Statistické hypotézy:

1. Neplavci tvoří nejvýše $10 \%$ celkového počtu studentů

2. $60 \%$ neplavců uplavalo stanovený limit 100 metrů

Druhá výzkumná otázka: Zlepšili se studenti během plaveckého výcviku?

Statistické hypotézy:

3. Třetina studentů uplavala limit

4. $60 \%$ všech studentů si zlepšilo svou plaveckou zdatnost

5. Plavecký výcvik nedokončilo maximálně $10 \%$ studentů

Třetí výzkumná otázka: Změnila se plavecká zdatnost studentů za 10 let? Statistická hypotéza:

6. Plavecká zdatnost studentů se za 10 let zlepšila 


\section{METODIKA}

Sledovali jsme plaveckou úroveň studentů UTB ve Zlíně od roku 2002 do roku 2013, a to $\mathrm{u}$ všech studentů, kteří se $\mathrm{v}$ těchto letech přihlásili do povinného předmětu plavání. $Z$ celkového počtu přihlášených jsme vždy vyhodnotili neplavce. V České republice je zažité považovat za plavce toho, kdo zvládne souvisle uplavat vzdálenost $200 \mathrm{~m}$. Překonání této vzdálenosti předpokládá jednak jistou úroveň plavecké techniky, jednak určitou míru kondičních schopností, především vytrvalosti. Zadané kritérium je pro velkou část běžné populace svízelně splnitelným požadavkem. Proto jsme za kriterium zvolili uplavání stometrové vzdálenosti libovolným způsobem.

Vyhodnotili jsme, kolik z původních neplavců dokázalo po absolvování výuky plavání uplavat 100 metrů libovolným způsobem a kolik se jich alespoň v plavání zlepšilo. U všech studentů jsme také porovnávali časy studentů na začátku a na konci plaveckého výcviku. Vyhodnotili jsme, kolik studentů se zlepšilo. Někteří studenti pro malou účast výuku plavání nedokončili. Sledovali jsme také počet studentů osvobozených z plavání.

\section{Použité matematické a statistické metody}

Prvních pět statistických hypotéz jsme podrobili proporčním testům. U šesté hypotézy byly použity dva statistické testy. Prvním testem byl Wilcoxonův párový test k porovnání plavecké zdatnosti studentů v akademických letech 2002/2003 a 2012/2013. Zjištovali jsme, zda se studenti na konci plaveckého výcviku zlepšili nebo naopak zhoršili. K nalezení odpovědi na otázku, zda se za 10 let plavecké dovednosti studentů zlepšily, jsme použili dvouvýběrový Wilcoxonův test. Všechny statistické testy byly ověřovány na hladině významnosti 0,05 . Pro šestou statistickou hypotézu jsme vypočetli také popisné statistiky naměřených časů na konci plaveckého výcviku.

\section{Charakteristika statistických souborů}

Při analýze dat jsme vycházeli z naměřených časů na začátku a na konci plaveckého výcviku. Pro proporční testy byla použita data z akademických let 2007/2008 až 2012/2013. Pro oba Wilcoxonovy testy byly použity naměřené časy na konci plaveckého výcviku $\mathrm{z}$ akademických let 2002/2003 a 2012/2013. První statistický soubor (akademický rok 2002/2003) obsahoval naměřené časy 148 studentů. Druhý statistický soubor (akademický rok 2012/2013) obsahoval naměřené časy 146 studentů. Data jsme zpracovávali v programech XLStatistics a SPSS.

V Tab. 1 jsou uvedeny výchozí údaje pro testování prvních pěti statistických hypotéz.

Tab. 1 Výchozí údaje v letech 2007 až 2013

\begin{tabular}{|c|c|c|c|c|c|c|c|c|}
\hline Rok & $\begin{array}{c}\text { Počet } \\
\text { studentů }\end{array}$ & Neplavci & $\begin{array}{c}\mathrm{Z} \text { nich } \\
\text { zlepšení } \\
\text { na konci }\end{array}$ & $\begin{array}{c}\mathrm{Z} \text { nich } \\
100 \mathrm{~m} \\
\text { na konci }\end{array}$ & $\begin{array}{c}\text { Celkem } \\
\text { uplavalo } \\
\text { limit }\end{array}$ & $\begin{array}{c}\text { Celkem } \\
\text { zlepšení } \\
\text { na konci }\end{array}$ & $\begin{array}{c}\text { Nedokončili } \\
\text { výuku } \\
\text { (neúčast) }\end{array}$ & Osvobozeni \\
\hline $2012 / 2013$ & 718 & 27 & 27 & 18 & 143 & 509 & 27 & 62 \\
\hline $2011 / 2012$ & 686 & 19 & 19 & 12 & 135 & 533 & 25 & 106 \\
\hline $2010 / 2011$ & 727 & 29 & 24 & 16 & 165 & 529 & 29 & 98 \\
\hline $2009 / 2010$ & 819 & 23 & 22 & 16 & 186 & 617 & 54 & 150 \\
\hline $2008 / 2009$ & 749 & 18 & 17 & 10 & 190 & 582 & 50 & 117 \\
\hline $2007 / 2008$ & 814 & 29 & 29 & 20 & 210 & 662 & 47 & 75 \\
\hline
\end{tabular}

Zdroj: Vlastní zpracování na základě našich zjištěných informací

Data byla analyzována za uvedené akademické roky. Data jsme záměrně nečlenili z hlediska pohlaví studentů, typu semestru, podle fakult a podobně. 


\section{VÝSLEDKY}

Tab. 2 a 3 obsahují výsledky ověřené první a druhé statistické hypotézy pro první výzkumnou otázku.

Tab. 2 Vyhodnocení první statistické hypotézy: Maximálně 10\% neplavců

\begin{tabular}{|c|c|c|c|c|}
\hline Akademický rok & Výběrový podíl & Testová statistika & p-hodnota & Významnost \\
\hline $2012 / 2013$ & $3,76 \%$ & $-5,5735$ & $1,25 \mathrm{E}-08$ & ANO \\
\hline $2011 / 2012$ & $2,77 \%$ & $-6,3122$ & $1,38 \mathrm{E}-10$ & ANO \\
\hline $2010 / 2011$ & $3,99 \%$ & $-5,4015$ & $3,31 \mathrm{E}-08$ & ANO \\
\hline $2009 / 2010$ & $2,81 \%$ & $-6,8588$ & $3,49 \mathrm{E}-12$ & ANO \\
\hline $2008 / 2009$ & $3,87 \%$ & $-5,5922$ & $1,12 \mathrm{E}-08$ & ANO \\
\hline $2007 / 2008$ & $3,56 \%$ & $-6,1246$ & $4,56 \mathrm{E}-10$ & ANO \\
\hline
\end{tabular}

Zdroj: Vlastní zpracování na základě našich zjišsěných informací

U první hypotézy jsme se zajímali o to, zda neplavci tvoří maximálně $10 \%$ z celkového počtu studentů. Všechny testové statistiky byly zařazeny do kritického oboru, p-hodnoty byly téměř nulové. Vzhledem k tomu, že jsou p-hodnoty nižší než hladina významnosti 0,05 , můžeme prohlásit, že podíl neplavců je nižší než $10 \%$. Tato statistická hypotéza byla prokázána ve všech analyzovaných letech.

Tab. 3 Vyhodnocení druhé statistické hypotézy: 60\% neplavců uplavalo limit

\begin{tabular}{|c|c|c|c|c|}
\hline Akademický rok & Výběrový podíl & Testová statistika & p-hodnota & Významnost \\
\hline $2012 / 2013$ & $66,67 \%$ & 3,6482 & 0,000132 & ANO \\
\hline $2011 / 2012$ & $63,16 \%$ & 1,6894 & 0,04557 & ANO \\
\hline $2010 / 2011$ & $82,76 \%$ & 12,5266 & 0 & ANO \\
\hline $2009 / 2010$ & $69,57 \%$ & 5,5905 & $1,14 \mathrm{E}-08$ & ANO \\
\hline $2008 / 2009$ & $34,48 \%$ & $-14,2566$ & 1 & NE \\
\hline $2007 / 2008$ & $68,97 \%$ & 5,22395 & $8,77 \mathrm{E}-08$ & ANO \\
\hline
\end{tabular}

Zdroj: Vlastní zpracování na základě našich zjištěných informací

U druhé hypotézy nás zajímalo, zda $60 \%$ neplavců uplavalo limit 100 metrů. Téměř všechny testové statistiky byly zařazeny do kritického oboru a p-hodnoty se blíží nule. Proto můžeme prohlásit, že $60 \%$ neplavců uplavalo stanovený limit 100 metrů. Výjimkou byl akademický rok 2008/2009. V tomto akademickém roce byl podíl neplavců, kteří stanovený limit uplavali, velmi nízký. Proto nebylo možné stanovenou hypotézu v akademickém roce 2008/2009 na hladině významnosti 0,05 prokázat. P-hodnota je vyšší než hladina významnosti 0,05 .

Tab. 4 až 6 obsahují výsledky ověřené třetí až páté statistické hypotézy u druhé výzkumné otázky. 
Tab. 4 Vyhodnocení třetí statistické hypotézy:Třetina studentů uplavala limit

\begin{tabular}{|c|c|c|c|c|}
\hline Akademický rok & Výběrový podíl & Testová statistika & p-hodnota & Významnost \\
\hline $2012 / 2013$ & $19,92 \%$ & $-7,4538$ & 1 & NE \\
\hline $2011 / 2012$ & $19,68 \%$ & $-7,4195$ & 1 & NE \\
\hline $2010 / 2011$ & $22,70 \%$ & $-5,9062$ & 1 & NE \\
\hline $2009 / 2010$ & $22,71 \%$ & $-6,2627$ & 1 & NE \\
\hline $2008 / 2009$ & $25,37 \%$ & $-4,4409$ & 0,9999 & NE \\
\hline $2007 / 2008$ & $25,80 \%$ & $-4,3687$ & 0,9999 & NE \\
\hline
\end{tabular}

Zdroj: Vlastní zpracování na základě našich zjištěných informací

Třetí statistická hypotéza se soustředila na to, zda třetina studentů uplavala požadovaný limit 100 metrů. Všechny testové statistiky byly zařazeny do oboru přijetí. P-hodnoty jsou vyšší než hladina významnosti 0,05 . Proto nejsme oprávněni prohlásit, že třetina studentů uplavala limit 100 metrů. Naše odhady úspěšnosti studentů byly př́liš optimistické.

Tab. 5 Vyhodnocení čtvrté statistické hypotézy: $60 \%$ studentů se zlepšilo

\begin{tabular}{|c|c|c|c|c|}
\hline Akademický rok & Výběrový podíl & Testová statistika & p-hodnota & Významnost \\
\hline $2012 / 2013$ & $70,89 \%$ & 5,9564 & $1,29 \mathrm{E}-09$ & ANO \\
\hline $2011 / 2012$ & $77,70 \%$ & 9,4630 & 0 & ANO \\
\hline $2010 / 2011$ & $72,76 \%$ & 7,0228 & $1,09 \mathrm{E}-12$ & ANO \\
\hline $2009 / 2010$ & $75,34 \%$ & 8,9611 & 0 & ANO \\
\hline $2008 / 2009$ & $77,70 \%$ & 9,8888 & 0 & ANO \\
\hline $2007 / 2008$ & $69,04 \%$ & 5,2647 & $7,03 \mathrm{E}-08$ & ANO \\
\hline
\end{tabular}

Zdroj: Vlastní zpracování na základě našich zjištěných informací

Čtvrtá hypotéza se soustředila na to, zda si $60 \%$ studentů zlepšilo své plavecké dovednosti. Všechny testové statistiky byly zařazeny do kritického oboru a p-hodnoty se blíží nule nebo se jí rovnají. Vzhledem k tomu, že p-hodnoty jsou nižší než hladina významnosti 0,05 , můžeme říci, že si $60 \%$ studentů naší univerzity zlepšilo svou plaveckou zdatnost.

Tab. 6 Vyhodnocení páté statistické hypotézy: Plavecký výcvik nedokončilo 10\% studentů

\begin{tabular}{|c|c|c|c|c|}
\hline Akademický rok & Výběrový podíl & Testová statistika & p-hodnota & Významnost \\
\hline $2012 / 2013$ & $3,76 \%$ & $-5,5735$ & $1,25 \mathrm{E}-08$ & ANO \\
\hline $2011 / 2012$ & $3,64 \%$ & $-5,5526$ & $1,41 \mathrm{E}-08$ & ANO \\
\hline $2010 / 2011$ & $3,99 \%$ & $-5,4016$ & $3,31 \mathrm{E}-08$ & ANO \\
\hline $2009 / 2010$ & $6,59 \%$ & $-3,2529$ & 0,0006 & ANO \\
\hline $2008 / 2009$ & $6,68 \%$ & $-3,0287$ & 0,0012 & ANO \\
\hline $2007 / 2008$ & $5,77 \%$ & $-4,0228$ & $2,88 \mathrm{E}-05$ & ANO \\
\hline
\end{tabular}

Zdroj: Vlastní zpracování na základě našich zjištěných informací

Pátá statistická hypotéza byla spojena s neúspěšností studentů ve výuce plavání. Očekávali jsme, že výuku plavání nedokončí maximálně $10 \%$ studentů. Všechny testové statistiky byly zařazeny do kritického oboru, p-hodnoty se bliží nule. Výsledky proporčních testů naznačují, že plavecký výcvik nedokončilo méně než $10 \%$ všech našich studentů. 
Šestá statistická hypotéza byla zaměřena na to, zda se plavecké dovednosti studentů za 10 let zlepšily. Porovnání popisných statistik u obou analyzovaných souborů ukazuje Tab. 7.

Tab. 7 Popisná statistika naměřených časů z akademických let 2002/2003 a 2012/2013

\begin{tabular}{|l|c|c|c|}
\hline \multicolumn{1}{|c|}{$\begin{array}{c}\text { Popisná } \\
\text { statistika }\end{array}$} & $\begin{array}{c}\text { Oba } \\
\text { soubory }\end{array}$ & $\begin{array}{c}\text { Akademický rok } \\
2002 / 2003\end{array}$ & $\begin{array}{c}\text { Akademický rok } \\
2012 / 2013\end{array}$ \\
\hline Rozsah souboru & 294 & 148 & 146 \\
\hline Aritmetický průměr & 2,01 & 1,94 & 2,09 \\
\hline Směrodatná odchylka & 0,259 & 0,286 & 0,202 \\
\hline Šikmost & $-1,203$ & $-0,709$ & $-1,95$ \\
\hline Minimální hodnota & 1,37 & 1,37 & 1,40 \\
\hline Medián & 2,09 & 2,05 & 2,13 \\
\hline Maximální hodnota & 2,43 & 2,43 & 2,35 \\
\hline
\end{tabular}

V obou akademických letech je přibližně stejný počet studentů. Průměrný naměřený čas na konci plaveckého výcviku byl lepší v akademickém roce 2002/2003 než v akademickém roce 2012/2013. Z těchto popisných statistik můžeme usuzovat, že se plavecká zdatnost za 10 let spíše zhoršila.

Tab. 8 znázorn̆uje porovnání plavecké zdatnosti studentů na počátku a na konci plaveckého výcviku v akademickém roce 2002/2003.

Tab. 8 Porovnání plavecké zdatnosti studentů v akademickém roce 2002/2003

\begin{tabular}{|c|c|c|c|c|}
\hline Počet studentů & Stejné časy & Testová statistika & p-hodnota & Významnost \\
\hline 148 & 9 & 8,471948 & $1,4 \mathrm{E}-17$ & ANO \\
\hline
\end{tabular}

Zdroj: Vlastní zpracování na základě našich zjištěných informací

Prostř̌ednictvím párového Wilcoxonova testu jsme analyzovali naměřené časy u 148 studentů. U devíti studentů se vyskytly stejné časy uplavání požadovaného limitu. O těchto studentech můžeme říci, že se jejich plavecké dovednosti nezměnily. Tyto studenty jsme $\mathrm{z}$ dalších analýz vyloučili. Analyzovali jsme tedy naměřené časy u 139 studentů.

Testová statistika byla zařazena do kritického oboru a p-hodnota se bliží nule. Z toho vyplývá, že si v akademickém roce 2002/2003 studenti svou plaveckou zdatnost zlepšili.

Tab. 9 znázorňuje porovnání plavecké zdatnosti studentů na počátku a na konci plaveckého výcviku v akademickém roce 2012/2013.

Tab. 9 Porovnání plavecké zdatnosti studentů v akademickém roce 2012/2013

\begin{tabular}{|c|c|c|c|c|}
\hline Počet studentů & Stejné časy & Testová statistika & p-hodnota & Významnost \\
\hline 146 & 5 & 7,036518 & $2,5 \mathrm{E}-11$ & ANO \\
\hline
\end{tabular}

Zdroj: Vlastní zpracování na základě našich zjištěných informací

Podobně jsme analyzovali naměřené časy na konci plaveckého výcviku pro akademický rok 2012/2013 u 146 studentů. U pěti studentů byly naměřeny stejné časy uplavání požadovaného limitu. Stejně jako u prvního statistického souboru můžeme o těchto studentech prohlásit, že se jejich plavecké dovednosti nezměnily. Proto jsme tyto studenty z další analýzy vyloučili. Analyzovali jsme tedy naměřené časy u 141 studentů. 
Testová statistika byla zařazena do kritického oboru a p-hodnota se blíží nule. Z toho vyplývá, že si v akademickém roce 2012/2013 studenti svou plaveckou zdatnost zlepšili.

Můžeme tedy říci, že si studenti v obou akademických letech plaveckou zdatnost zlepšili.

Tab. 10 obsahuje výsledky ověřené šesté statistické hypotézy u třetí výzkumné otázky.

Tab. 10 Vyhodnocení šesté statistické hypotézy: Zlepšení plavecké zdatnosti studentů za 10 let

\begin{tabular}{|c|c|c|c|}
\hline Počet studentů & Testová statistika & p-hodnota & Významnost \\
\hline 294 & 5,33113 & $9,78 \mathrm{E}-08$ & ANO \\
\hline
\end{tabular}

Zdroj: Vlastní zpracování na základě našich zjištěných informací

Dvouvýběrovým Wilcoxonovým testem jsme ověřovali, zda se plavecká zdatnost studentů za 10 let zlepšila. Testová statistika podobně jako u obou párových Wilcoxonových testů byla zařazena do kritického oboru. P-hodnota se blíží nule a je nižší než hladina významnosti 0,05 . Můžeme tedy prohlásit, že se plavecká zdatnost za 10 let u studentů Univerzity Tomáše Bati ve Zlíně výrazně zlepšila.

\section{DISKUSE}

Provedené statistické testy prokázaly platnost našich výchozích předpokladů. Odhady podílů byly uspokojivé a můžeme říci, že i reálné. Výsledky nejsou podle našeho názoru uspokojivé. Mezi studenty je řada neplavců.

Z Tab. 1 vyplývá, že od roku 2007 do roku 2013 jsme zaznamenali 145 neplavců. Kromě šesti neplavců se na konci plaveckého výcviku zlepšilo 138 neplavců. Zajímavé zjištění bylo, že se v akademických letech 2007/2008, 2011/2012 a 2012/2013 zlepšili všichni neplavci. Horších výsledků dosáhli neplavci při uplavání požadovaného limitu 100 metrů. Tento limit uplavalo 92 neplavců. Jsme rádi za to, že se 60 \% neplavců na konci plaveckého výcviku zlepšilo.

Výsledky statistických testů mohou zkreslovat studenti, kteří plavecký výcvik nedokončili nebo byli z plavání osvobozeni. Studenti, kteří z libovolného důvodu nedokončili plavecký výcvik, mohou být plavci i neplavci. Studenti, kteří byli z plavání osvobozeni, mohou být spíše neplavci, kteří se plavání vyhýbají. Pokud by takoví studenti byli zařazeni do analýzy, mohlo by se prokázat, že třetina studentů uplavala požadovaný limit 100 metrů. Požadovaný limit 100 metrů uplavalo 1029 studentů.

Výsledky našeho výzkumu nemohou být srovnatelné s výsledky jiných autorů. Mikyna (2013) analyzoval plaveckou zdatnost vysokoškolských studentů podobně jako my. Testoval však tři různé plavecké styly: prsa, znak a kraul. My jsme testovali uplavání 100 metrů libovolným plaveckým způsobem. Pokud bychom testovali stejné plavecké styly, mohli bychom výsledky porovnat. Mikyna (2013) použil pro analýzu dat pouze popisné statistiky (aritmetický průměr, medián, směrodatná odchylka). Statistický test nebyl v bakalářské práci použit.

Jánošíková (2010) analyzovala plaveckou zdatnost žáků v Plavecké škole ve Valašském Meziříčí. My jsme testovali plaveckou zdatnost vysokoškolských studentů. Výsledky není možné srovnávat z důvodů nižší plavecké zdatnosti žáků základní školy. Jánošíková (2010) zjištovala jen to, zda žák dokáže splývat a uplavat vzdálenost 25 metrů plaveckým stylem prsa. My jsme zjištovali uplavání limitu 100 metrů libovolným způsobem. Jánošíková (2010) použila stejný statistický test (neparametrický dvouvýběrový Wilcoxonův test) jako my. Nás navíc zajímalo také to, zda se studenti za 10 let zlepšili.

Celkově však můžeme říci, že si většina studentů zlepšila svou plaveckou zdatnost na konci 
plaveckého výcviku. Na konci plaveckého výcviku se zlepšilo 3432 studentů, což představuje $76 \%$ všech analyzovaných studentů.

Původně jsme očekávali, že se plavecká zdatnost za 10 let u studentů zhorší. Svědčí o tom průměrné naměřené časy u analyzovaných studentů. Byli jsme však př́ijemně překvapeni, že se plavecká zdatnost studentů Univerzity Tomáše Bati za 10 let zlepšila.

Pro výuku plavání na Univerzitě Tomáše Bati ve Zlíně doporučujeme:

1. Ověřovat plaveckou zdatnost studentů na počátku plaveckého výcviku jako jsme prováděli doposud.

2. Rozdělit studenty na plavce a neplavce.

3. Motivovat plavce i neplavce ke zlepšení plaveckých dovedností, aby byli schopni uplavat stanovený limit 100 metrů v lepším čase než na počátku plaveckého výcviku.

4. V polovině semestru provádět kontrolní měření plavecké zdatnosti u plavců i u neplavců a zjištovat jejich zlepšení.

5. Používat tytéž statistické testy k porovnání zlepšení či zhoršení plavecké zdatnosti studentů Univerzity Tomáše Bati na počátku plaveckého výcviku a u kontrolního měření.

6. Používat tytéž statistické testy k porovnání zlepšení či zhoršení plavecké zdatnosti studentů Univerzity Tomáše Bati u kontrolního měření a na konci plaveckého výcviku.

7. Používat tytéž statistické testy k porovnání zlepšení či zhoršení plavecké zdatnosti studentů Univerzity Tomáše Bati na počátku plaveckého výcviku a na konci plaveckého výcviku.

8. Dlouhodobě sledovat plaveckou zdatnost studentů Univerzity Tomáše Bati ve Zlíně.

\section{ZÁVĚRY}

Cílem článku bylo porovnání plavecké zdatnosti studentů Univerzity Tomáše Bati ve Zlíně v akademických letech 2002/2003 až 2012/2013. Zajímalo nás, zda si neplavci mohou zlepšit svou plaveckou zdatnost na konci plaveckého výcviku, zda se studenti během plaveckého výcviku zlepšili a zda se změnila plavecká zdatnost studentů za 10 let.

Odpověd' na otázku, zda jsou neplavci schopni zlepšit si svou plaveckou zdatnost na konci plaveckého výcviku, vyplývá z ověřené první a druhé statistické hypotézy. Bylo prokázáno, že neplavci tvoří méně než $10 \% \mathrm{z}$ celkového počtu studentů. $Z$ celkového počtu 145 neplavců se 138 na konci plaveckého výcviku zlepšilo. V akademických letech 2007/2008, 2011/2012 a 2012/2013 se zlepšili všichni neplavci. 92 neplavců uplavalo limit 100 metrů. 60 \% neplavců na konci plaveckého výcviku zlepšilo.

Odpověd' na otázku, zda se studenti během plaveckého výcviku zlepšili, není jednoznačná. Svědčí o tom nepotvrzená třetí statistická hypotéza o tom, že třetina studentů neuplavala limit 100 metrů. Požadovaný limit uplavalo celkem 1029 studentů. Na konci plaveckého výcviku se zlepšilo 3432 studentů.

U třetí výzkumné otázky jsme předpokládali zhoršení plavecké zdatnosti studentů. Svědčily o tom naměřené časy i vypočtené popisné statistiky. Byli jsme však př́jjemně překvapeni, že se plavecká zdatnost studentů Univerzity Tomáše Bati za 10 let zlepšila.

Doporučujeme, aby plavecká zdatnost studentů byla ověřována na počátku i konci plaveckého výcviku zvlášt u plavců a neplavců. Dále doporučujeme zařadit kontrolní měření zlepšení či zhoršení plavecké zdatnosti plavců i neplavců. Doporučujeme motivovat plavce i neplavce k dalšímu zlepšení plavecké zdatnosti. Bude vhodné zařadit stejné statistické testy na počátku i na konci plaveckého výcviku a do kontrolních měření. Plaveckou zdatnost našich studentů budeme dlouhodobě sledovat.

Analyzovali jsme plaveckou zdatnost studentů Univerzity Tomáše Bati ve Zlíně. K analýze jsme použili jednoduché statistické testy. Tento postup může být přínosný $\mathrm{k}$ analýze plavecké zdatnosti nejen na dalších vysokých školách, ale na různých pracovištích, která se zabývají měřením zdatnosti sportovců. 
Předpokládáme zveřejnění dalších výsledků plavecké zdatnosti studentů naší univerzity. Autoři uvítají jakoukoliv spolupráci v analýze plavecké zdatnosti studentů i sportovců.

\section{Literatura}

Arroyo-Toledo, J. J, Clemente, V. J. \& Gonzáles-Ravé, J. M. (2013). The effects of ten weeks block and reverse periodization training on swimming performance and body composition of moderately trained female swimmers. Journal of Swimming Research, 21(1). Retrieved from: http://www.swimmingcoach.org/journal/manuscript-arroyo-toledo.pdf

Jánošíková J. (2010). Zhodnocení úspěšnosti základního plaveckého výcviku (bakalářská práce, Univerzita Palackého, Fakulta tělesné kultury, Olomouc). Retrieved from: https://theses.cz/id/16kpps

Labudová, J. \& Matúš, I. (2010). Analýza úrovne silových schopností synchronizovaných plavkýň. Studia sportiva, 4(1), 43-52. Retrieved from: http://www.fsps.muni.cz/studiasportiva/dokument/studia_sportiva_2010_4_1.pdf

Martinková, A. (2012). Plavecká úroveň vysokoškolské populace na UTB ve Zlíně (diplomová práce, Univerzita Palackého, Fakulta tělesné kultury, Olomouc). Retrieved from: http://theses.cz/id/kt81uu/uplne_nejnovejsi_verze_DP1.pdf

Merica, M. \& Hlavatý, R. (2010). Monitoring of Anthropometric Characteristics of Swimmers. Studia sportiva, 4(1), 13-16. Retrieved from: http://www.fsps.muni.cz/studiasportiva/dokument/studia_sportiva_2010_4_1.pdf

Mikyna, J. (2013). Úroveň plaveckých dovedností studentů jednotlivých oborů na FSpS MU (bakalářská práce, Masarykova univerzita, Fakulta sportovních studií, Brno). Retrieved from: http://is.muni.cz/th/380873/fsps_b/Bakalarka_-_Jaroslav_ Mikyna.pdf

Stloukalová, B., Roztočil, T. \& Vrabcová, M. (2010). Základní plavecké dovednosti ve výuce plavání. Studia sportiva, 4(2), 5968. Retrieved from: http://www.fsps.muni.cz/studiasportiva/dokument/studia_sportiva_2010_4_2.pdf

Vodní záchranná služba Českého červeného kříže (2013). Statistika utonulých v ČR. Retrieved from: https://docs.google. com/a/vzs.cz/spreadsheet/ccc?key=0Ah-yslzgfOvydDlyclBxUkp4RVo3SkZ5RnB4T3FYTXc\#gid=0 